\title{
Correction to: Enamel Microstructure in Cetacea: a Case Study in Evolutionary Loss of Complexity
}

\author{
Alexander J. Werth ${ }^{1}$ (D) $\cdot$ Carolina Loch $^{2} \cdot$ R. Ewan Fordyce ${ }^{3}$
}

Published online: 14 September 2019

(C) Springer Science+Business Media, LLC, part of Springer Nature 2019

\section{Correction to: Journal of Mammalian Evolution} https://doi.org/10.1007/s10914-019-09484-7

Credit for the Basilosaurus tooth photograph in Figure 9a: Aaron Miller, Ancient Earth Trading Company LLC. Also, please note that individual teeth shown in both Figure 2 and Figure 9 were not the specific sources of accompanying enamel photomicrographs.

The online version of the original article can be found at https://oi.org/ 10.1007/s10914-019-09484-7

\footnotetext{
Alexander J. Werth

awerth@hsc.edu

1 Department of Biology, Hampden-Sydney College, Hampden-Sydney, VA 23943, USA

2 Sir John Walsh Research Institute, Faculty of Dentistry, University of Otago, Dunedin 9054, New Zealand

3 Department of Geology, University of Otago, Dunedin 9054, New Zealand
} 